\title{
Identification of genes regulated by interleukin-1 $\beta$ in human endometrial stromal cells
}

\author{
Marco Rossi, Andrew M Sharkey ${ }^{1}$, Paola Viganò ${ }^{2}$, Giovina Fiore, Rob Furlong ${ }^{1}$, Pasquale Florio, \\ Guido Ambrosini ${ }^{3}$, Stephen K Smith ${ }^{4}$ and Felice Petraglia
}

Obstetrics and Gynaecology, Department of Paediatrics, Obstetrics and Reproductive Medicine, University of Siena, Italy, ${ }^{1}$ Department of Pathology, University of Cambridge, Cambridge, UK, ${ }^{2}$ Molecular Laboratory Auxologic Centre, Milan, Italy, ${ }^{3}$ Department of Gynaecological Science and Reproductive Medicine, University of Padua School of Medicine, Padua, Italy and ${ }^{4}$ Faculty of Medicine Centre, Imperial College, London, UK

Correspondence should be addressed to F Petraglia, Obstetrics and Gynaecology, Department of Paediatrics, Obstetrics and Reproductive Medicine, University of Siena, Policlinico 'Le Scotte', Viale Bracci, 53100 Siena, Italy; Email: petraglia@unisi.it

\begin{abstract}

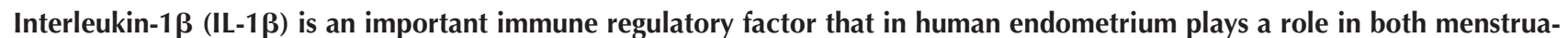
tion and implantation in the event of pregnancy. It promotes inflammatory-like processes and also stimulates tissue remodelling. We present a cDNA microarray study documenting the major effects of IL-1 $\beta$ on gene expression in stromal cells from human endometrium. Endometrial stromal cells from five normal healthy women at the mid secretory phase were cultured with or without IL-1 $\beta$ at 50 and $500 \mathrm{pg} / \mathrm{ml}$ for $48 \mathrm{~h}$. cDNA microarrays were used to compare the levels of gene expression in total RNA isolated from cells stimulated with IL-1 $\beta$. These cDNA arrays were produced containing 15164 sequence-verified clones, which included genes known to be important in angiogenesis, immune modulators, apoptosis, cell signalling, extracellular matrix (ECM) remodelling and cell cycle regulation. Genes which were regulated by IL-1 $\beta$ were identified by analysis of the microarray data using the Significance Analysis of Microarrays software package. Upregulated $(n=23)$ and downregulated $(n=6)$ different genes were observed, which changed at least 3 -fold, at a false discovery rate of less than $2 \%$

$(P<0.02)$. Our results have identified genes regulated by IL-1 $\beta$, which are involved in leukocyte recruitment, ECM remodelling and other cellular functions. Changes in three genes, IL-8, colony-stimulating factor 2 and aldo-keto reductase family 1 member 1, which were upregulated by IL-1 $\beta$, were verified using real-time PCR. Novel functions regulated by IL-1 $\beta$ in endometrium, including genes involved in free radical protection, and fatty acid metabolism were also identified. These results also provide new insights into the role of IL-1 $\beta$ in disorders of the endometrium, especially in implantation-related infertility and endometriosis, in which this cytokine plays a major role.
\end{abstract}

Reproduction (2005) $130721-729$

\section{Introduction}

During each menstrual cycle, the human endometrium undergoes to a complex process of growth and remodelling, in preparation for embryo implantation. Although this cycle is under the control of ovarian steroid hormones, many of their actions are mediated by local factors such as cytokines and growth factors. These regulate functions such as endometrial growth, menstruation, infection prevention, implantation and decidualisation (Arici et al. 1993, Sharkey 1998).

Among these factors, interleukin-1 $\beta$ (IL-1 $\beta$ ) is believed to play a role in tissue remodelling and in inflammatorylike response that occur in the human endometrium at menstruation. It is also implicated in critical reproductive functions such as embryo attachment and decidualisation
(Frank et al. 1995, Simon et al. 1995, 1997). IL-1 $\beta$ is a $30 \mathrm{kDa}$ polypeptide produced mainly by blood monocytes as a mediator of the inflammatory response, but it also controls cell proliferation, differentiation and apoptosis (Dinarello 1996). In the human endometrium, IL-1 $\beta$ immunoreactivity has been detected in the stroma and epithelium as well as on macrophages and endothelial cells, with maximal mRNA expression in the mid to late secretory phase (Kauma et al. 1990, Tabibzadeh \& Sun 1992). Other members of the IL- 1 family include IL- $1 \alpha$ and the antagonist IL-1 ra, both of which are expressed in endometrium (Tabibzadeh \& Sun 1992, Simon et al. 1995). These bind to two receptors: the IL-1 receptor type I (IL-1R1), which is required for signal transduction, and the decoy receptor IL-1R type II. IL-1R1 expression has 
been reported on epithelial and stromal cells, with maximal expression in the mid and late secretory phase (Simon et al. 1994, Bigonnesse et al. 2001, Boucher et al. 2001). Previous reports have demonstrated that IL-1 $\beta$ stimulates changes in cytokines, growth factors and adhesion molecules in both epithelial and stromal cells of the human endometrium (Simon et al. 1994, Nasu et al. 2001). Moreover, IL-1 $\beta$ secreted by the human embryo may act as signal to the endometrium (De los Santos et al. 1996, Krussel et al. 2003). Indeed, high concentrations of IL-1 $\beta$ in the culture media of human embryos have been correlated with successful implantation after in vitro fertilisation (Sheth et al. 1991, Barañao et al. 1992, Spandorfer et al. 2000). A critical role in early implantation is also suggested by the fact that IL-1 ra blocks the response of the endometrium to human chorionic gonadotrophin (hCG) from the pre-implantation in the baboon (Strakova et al. 2005). Perhaps the best-documented effect of IL-1 $\beta$ is on the process of decidualisation, where it has been shown to inhibit stromal cell decidualisation (Frank et al. 1995). Finally, this cytokine may be involved in several other pathophysiological functions, such as endometriosis where stromal cells from ectopic endometriotic lesions have been shown to have altered responses to IL-1 $\beta$ compared with normal eutopic stromal cells (Lebovic et al. 2002). It has been argued that the effect of elevated levels of IL-1 $\beta$ in the peritoneum on refluxed endometrium may contribute to the vascularisation and establishment of ectopic endometriotic lesions.

The present study aimed to determine the effect of IL-1 $\beta$ on human endometrial stromal cells (HESCs) collected during the secretory phase using a microarray-based approach.

\section{Materials and Methods}

\section{Reagents}

Human recombinant IL-1 $\beta$ was purchased from Amersham International. Culture medium consisted of Ham's F-10 (Euroclone, Wetherby, West Yorks, UK) supplemented with $2 \mathrm{mM}$ L-glutamine, $100 \mathrm{U} / \mathrm{ml}$ penicillin, $100 \mu \mathrm{g} / \mathrm{ml}$ streptomycin, $2.5 \mu \mathrm{g} / \mathrm{ml}$ Fungizone and $10 \%$ fetal calf serum (all from Euroclone). Collagenase A was purchased from Roche Molecular Biochemicals (Milan, Italy).

\section{Cells preparation and cultures}

Human endometrium was obtained at laparoscopy from five normally cycling fertile healthy volunteers (28-37 years of age). Permission of the Human Investigation Committee of the University of Siena was granted for the experiments, and patients gave their informed consent.

Subjects were free of uterine diseases and did not use any contraceptive steroids for at least 6 months prior to biopsy. All specimens of endometrium were obtained in the mid to late (18-24 day) secretory phase, based on the date of the last menstrual period, on the ultrasound evaluation and confirmed by histological examination of the samples (Noyes et al. 1975). HESCs were separated as described previously (Viganò et al. 2002). Briefly, tissue samples were gently minced into small pieces $\left(1-2 \mathrm{~mm}^{3}\right)$ and incubated for $2 \mathrm{~h}$ at $37^{\circ} \mathrm{C}$ in a shaking water bath in $10 \mathrm{ml} \mathrm{Ham}$ 's F-10 containing $0.1 \%$ collagenase. At the end of the incubation, single stromal cells were separated from large clumps of epithelium by a $10 \mathrm{~min}$ period of differential sedimentation at unit gravity. The top $8 \mathrm{ml}$ of medium, containing predominantly stromal cells, were then slowly removed, and the cells were collected by centrifugation, washed twice in culture medium and allowed to adhere selectively to tissue culture dishes for $20 \mathrm{~min}$. Thereafter, any non-attached epithelial cells still present were removed, and a purified stromal preparation was obtained on the surface of the culture dishes. Immunostaining with vimentin was used to verify the purity of the stromal cell cultures, which showed less than $1 \%$ epithelial contamination. Cells were counted, and flow cytometric analysis was performed to determine the possible contamination of CD45/CD14-positive cells. Cultures in which there were more than $2 \%$ CD45-positive cells were not included in the study. Cells were cultured for 6 days in $60 \mathrm{~mm}$ dishes at a density of $5 \times 10^{5} /$ dish to achieve confluence. For the next $48 \mathrm{~h}$ the cells were grown in serum-free medium, and then stimulated with IL- $1 \beta$ at 50 or $500 \mathrm{pg} / \mathrm{ml}$ for a further $48 \mathrm{~h}$. In total from five patients we have treated three different sample cultures with or without IL-1 $1 \beta$ at $50 \mathrm{pg} / \mathrm{ml}$ and three with IL-1 $\beta$ at $500 \mathrm{pg} / \mathrm{ml}$. All incubations were performed in a humidified atmosphere at $37^{\circ} \mathrm{C}$ in $5 \% \mathrm{CO}_{2}$.

\section{RNA extraction from HESCs}

Total RNA was separately extracted from HESCs using Trizol Reagent (Invitrogen) and then treated with DNAse (Ambion, Inc., Austin, TX, USA) according to the manufacturer's instructions. RNA quality was assessed by loading $200 \mathrm{ng}$ total RNA onto an RNA Labchip (Agilent Technologies, Waldbronn, Germany) and analysed on an A2100 Bioanalyser (Agilent Technologies).

\section{Preparation of cDNA glass array (printing of HMN cDNAs on GAPSII slides)}

The microarray was printed on two slides using cDNA clones derived from four main sources: (i) 5856 cDNA clones came from the Mammalian Gene Collection (http://mgc.nci.nih.gov/); (ii) 3360 clones of the HuGen set were purchased from the UK Human Genome Mapping Project (HGMP) Resource Centre (MRC Geneservice, Babraham Bioincubator, Babraham, Cambridge, UK); (iii) 4992 clones from a normalised human testis set IMAGE (http://image.IInl.gov/) were also obtained from HGMP; and (iv) the Angiogenesis/Apoptosis cDNA set (956 clones) were developed in the Department of Pathology, University of Cambridge specifically for the study of endometrial biology 
(Evans et al. 2003). Human cDNA inserts were PCR amplified from bacterial lysates using vector-specific primers and the purified PCR products were printed onto GAPSII aminosilane slides (Corning, NY, USA) in $150 \mathrm{mM}$ phosphate $\mathrm{pH}$ 8.5/0.01\% SDS buffer using a BioRobotics 610 MicroGrid II robot and MicroSpot 2500 quill pins (BioRobotics, Cambridge, UK). Spot sizes varied from approximately 120 to $160 \mu \mathrm{m}$ diameter. Slides were fixed after printing by baking on a hot plate at $80^{\circ} \mathrm{C}$ for $2 \mathrm{~h}$. They were then blocked by immersion in 1\% BSA (Molecular Biology grade B2518; Sigma-Aldrich) $+0.1 \%$ SDS in $3 \times$ SSC for 20 min at $65^{\circ} \mathrm{C}$, and then denatured by immersion in double-distilled $\mathrm{H}_{2} \mathrm{O}$ at $95^{\circ} \mathrm{C}$ for $2 \mathrm{~min}$. Slides were finally immersed in isopropanol before drying by centrifugation. They were stored in a dry, dark environment at room temperature.

\section{Preparation of fluorescence-labelled targets and CDNA microarray hybridisation}

cDNA synthesis and labelling for hybridisation was carried out using the procedure of Petalidis et al. (2003) with minor modifications. One microgram of total RNA was used to synthesise double-stranded cDNA (ds-cDNA) with a SMART PCR cDNA synthesis Kit (Clontech, Oxford, UK) according to the manufacturer's instructions. The ds-cDNA from untreated and IL-1 $\beta$-treated HESCs was labelled by Cy3-deoxyuridine triphosphate and Cy5-deoxyuridine triphosphate (Amersham) respectively, using the Bioprime DNA labelling kit (Invitrogen) with random hexamers. These paired samples were purified using Autoseq G50 columns (Amersham), pooled with $5 \mu \mathrm{g} / \mathrm{ml}$ human Cot-1 DNA (Life Technologies) and $1 \mu \mathrm{g} / \mathrm{ml}$ Poly dA (Amersham) and hybridised to the cDNA microarray at $50^{\circ} \mathrm{C}$ for $16 \mathrm{~h}$. The arrays were washed twice in $2 \times \mathrm{SSC}, 0.5 \%$ SDS and twice in $0.1 \times$ SSC, $0.1 \%$ SDS for $5 \mathrm{~min}$ and twice with $0.1 \times$ SSC, each at room temperature. The fluorescence signal on microarrays was acquired by using a Genepix 4100 microarray scanner (Axon Instruments, Foster City, CA, USA). The scanned images were processed by using GenePix Pro 3.0 software (Axon Instruments).

\section{Array analysis}

The raw data were normalised per spot and per chip using GeneSpring 6 software with intensity-dependent (Lowess) normalisation (per cent of the data used for smoothing $10 \%)$ and per chip normalised to the 50th percentile. Low hybridisation signals were removed to give an average of 5000 different genes expressed above background. Experimental interpretation was based on dose treatment of IL$1 \beta$ : three samples treated with IL- $1 \beta$ at $50 \mathrm{pg} / \mathrm{ml}$ and three with $500 \mathrm{pg} / \mathrm{ml}$. To identify genes whose expression was altered by IL- $1 \beta$ the normalised and filtered Cy 5 and Cy3 values for each array were analysed with SAM version 1.21 (Significance Analysis of Microarrays; Stanford University) (Tusher et al. 2001). SAM identifies genes with statistically significant changes in expression by assimilating a set of gene-specific t-tests. Each gene is assigned a score on the basis of its change in gene expression relative to the S.D. of repeated measurement for that gene. Genes with scores greater than a threshold are deemed potentially significant. The percentage of such genes identified by chance is the false discovery rate (FDR). The criteria used to obtain genes that were significantly up- or downregulated were: an FDR less than 2\% and a fold change greater than 3 in all three samples.

\section{Real-time PCR verification}

In order to verify the results obtained from the cDNA microarray, real-time PCR (Taqman) verification was performed for three genes: IL-8, colony-stimulating factor 2 (CSF2) and aldo-keto reductase family 1 member B1 (AKR1B1). Relative expression levels of each gene in the control and IL-1 $\beta$-treated cells were determined using primers obtained from Applied Biosystems (Assays-ondemand) in accordance to the manufacturer's instructions. Standard curves were generated by serial dilution of a standard preparation of total RNA isolated from an untreated HESC sample. Data are expressed in arbitrary units relative to the level of the same gene in this standard RNA. CDNA was produced from each HESC sample by reverse transcription with random hexamers using $5 \mu \mathrm{g}$ total RNA with $200 \mathrm{IU}$ Superscript RT (Invitrogen). The expression values obtained were normalised against those from the control ribosomal $18 \mathrm{~S}$ to account for differing amounts of starting material. Expression levels in the IL$1 \beta$-treated and control cells were compared using the Wilcoxon matched-pairs test. Differences were considered statistically significant at $P<0.05$.

\section{Results}

\section{Microarray analysis}

Total RNA was isolated from primary HESCs from five patients and treated in vitro with either 50 or $500 \mathrm{pg} / \mathrm{ml} \mathrm{IL-}$ $1 \beta$. RNA from IL-1 $\beta$-treated cells was compared by microarray with the corresponding untreated control cells from the same patient. Genes whose expression was altered by either dose of IL-1 $\beta$ were identified by SAM analysis (Tables 1-3). Only those whose expression was significantly altered as defined by SAM software by more than 3-fold in all patients and with an FDR less than $2 \%$ are shown $(q$ value $=0.0195 ; q$ value is similar to the wellknown $P$ value, but adapted to multiple-testing situations). We identified 13 upregulated genes with IL-1 $50 \mathrm{pg} / \mathrm{ml}$ (Table 1), 23 upregulated genes with IL-1 $500 \mathrm{pg} / \mathrm{ml}$ (Table 2), one downregulated gene with IL-1 $\beta 50 \mathrm{pg} / \mathrm{ml}$ and six downregulated with IL-1 $500 \mathrm{pg} / \mathrm{ml}$ (Table 3). We classified the genes into known functional groups based on information retrieved from the National Center for Biotechnology Information/Entrez/Online Mendelian Inheritance in Man database search. In each Table, the genes are ranked in descending order of the average of the fold change. For genes upregulated by IL-1 $\beta$, the average 
Table 1 IL-1 $50 \mathrm{pg} / \mathrm{ml}$ upregulated genes.

\begin{tabular}{|c|c|c|c|c|}
\hline GenBank & Name & Fold change & Signal intensity & Description \\
\hline \multicolumn{5}{|c|}{ Immune modulators/cytokines } \\
\hline X12510 & CXCL1 & 11.7 & 25000 & Chemokine (C-X-C motif) ligand 1 \\
\hline M11220 & CSF2 & 9.4 & 15000 & Granulocyte-macrophage colony-stimulating factor \\
\hline W47101 & $\mathrm{IL}-1 \beta$ & 8.1 & 12000 & Interleukin 1 , beta \\
\hline M26383 & IL-8 & 7.8 & 9000 & Interleukin 8 \\
\hline M36820 & CXCL2 & 3.7 & 7000 & Chemokine (C-X-C motif) ligand 2 \\
\hline K02765 & $\mathrm{C} 3$ & 4.5 & 5000 & Complement component 3 \\
\hline AA403048 & CCL13 & 4.5 & 3000 & Chemokine (C-C motif) ligand 13 \\
\hline W39456 & CCL7 & 3.7 & 4500 & Chemokine (C-C motif) ligand 7 \\
\hline R95077 & CXCL5 & 3.6 & 3300 & Chemokine (C-X-C motif) ligand 5 \\
\hline \multicolumn{5}{|c|}{ Detoxification and other functions } \\
\hline R10693 & AMPD3 & 5.2 & 4700 & Adenosine monophosphate deaminase $\mathrm{E}$ \\
\hline R92994 & MMP12 & 4.2 & 16000 & Matrix metalloproteinase 12 \\
\hline BC007034 & MT2A & 3.7 & 14000 & Metallothionein $2 \mathrm{~A}$ \\
\hline W56188 & AKR1B1 & 3.3 & 55000 & Aldo-keto reductase family 1 , member $\mathrm{B} 1$ \\
\hline
\end{tabular}

Signal intensity is the average signal from all the samples after treatment with IL-1 $\beta$.

Table 2 IL-1 $500 \mathrm{pg} / \mathrm{ml}$ upregulated genes.

\begin{tabular}{|c|c|c|c|c|}
\hline GenBank & Name & Fold change & Signal intensity & Description \\
\hline \multicolumn{5}{|c|}{ Immune modulators/cytokines } \\
\hline X12510 & CXCL1 & 31.2 & 30000 & Chemokine (C-X-C motif) ligand 1 \\
\hline M17706 & CSF3 & 23.3 & 15000 & Granulocyte colony-stimulating factor \\
\hline W47101 & IL-1 $\beta$ & 13.3 & 20000 & Interleukin 1, beta \\
\hline M11220 & CSF2 & 12.3 & 22000 & Granulocyte-macrophage colony-stimulating factor \\
\hline M26383 & IL-8 & 11 & 14000 & Interleukin 8 \\
\hline M28226 & CCL2 & 10.4 & 18000 & Chemokine (C-C motif) ligand 2 \\
\hline W39456 & CCL7 & 9.4 & 13000 & Chemokine (C-C motif) ligand 7 \\
\hline K02765 & $\mathrm{C} 3$ & 7.8 & 8000 & Complement component 3 \\
\hline M18403 & IL6 & 7.7 & 8000 & Interleukin 6 (interferon, beta 2) \\
\hline R95077 & CXCL5 & 7.3 & 5000 & Chemokine ( $\mathrm{C}-\mathrm{X}-\mathrm{C}$ motif) ligand 5 \\
\hline AA448801 & TNFAIP6 & 5.2 & 12000 & Tumour necrosis factor, $\alpha$-induced protein 6 \\
\hline M36820 & CXCL2 & 5 & 1000 & Chemokine (C-X-C motif) ligand 2 \\
\hline AA403048 & CCL13 & 3.7 & 3000 & Chemokine (C-C motif) ligand 13 \\
\hline Al015062 & LCP1 & 3 & 4500 & Lymphocyte cytosolic protein (L-plastin) \\
\hline \multicolumn{5}{|c|}{ Multiple cellular functions } \\
\hline W56188 & AKR1B1 & 3.7 & 56000 & Aldo-keto reductase family 1 , member $\mathrm{B} 1$ \\
\hline R10693 & AMPD3 & 3.7 & 7000 & Adenosine monophosphate deaminase $\mathrm{E}$ \\
\hline BC007460 & ACPP & 3.4 & 10000 & Acid phosphatase, prostate \\
\hline 03223 & PRG1 & 3.1 & 2000 & Proteoglycan 1 , secretory granule \\
\hline \multicolumn{5}{|c|}{ ECM remodelling } \\
\hline L23808 & MMP12 & 8.5 & 8000 & Matrix metalloproteinase 12 \\
\hline R94935 & PAI2 & 3.4 & 3000 & Plasminogen activator inhibitor 2 \\
\hline M13509 & MMP1 & 3 & 9000 & Matrix metalloproteinase 1 \\
\hline \multicolumn{5}{|l|}{ Detoxifications } \\
\hline BC007034 & MT2A & 3.2 & 10000 & Metallothionein 2A \\
\hline X14322 & SOD2 & 3 & 4500 & Superoxide dismutase 2 , mitochondrial \\
\hline
\end{tabular}

Signal intensity is the average of the samples after treatment with IL-1 $\beta$.

signal intensity of each cDNA for all the samples following IL-1 $\beta$ treatment is shown in Tables 1 and 2 . For downregulated genes, the signal intensity listed in Table 3 is the average of the control (untreated) samples. The signal intensity of the hybridisation for each cDNA on the microarray that was found to change is listed because although this is not always clearly related to the amount of the corresponding transcript, it usually gives some idea of the abundance of that transcript.

From the functional classification, it is clear that several groups of genes with related functions were upregulated. As expected, the largest group were the immune modulators, with many chemokines and cytokines strongly upregulated. Expression of several metalloproteinases and protease inhibitors was also altered, in agreement with known effects of IL-1 $\beta$ on endometrial remodelling.

\section{Real-time verification}

Real-time PCR analysis of specific gene transcripts in HESC mRNA from untreated cells and cells stimulated with IL-1 $\beta$ 
Table 3 IL-1 $\beta$ down regulated genes.

\begin{tabular}{|c|c|c|c|c|}
\hline GenBank & Name & Fold change & Signal intensity & Description \\
\hline \multicolumn{5}{|l|}{$I L-1 \beta 50 \mathrm{pg} / \mathrm{ml}$} \\
\hline \multicolumn{5}{|l|}{$I L-1 \beta 500 \mathrm{pg} / \mathrm{ml}$} \\
\hline$\times 57766$ & MMP11 & 4.5 & 2900 & Matrix metalloproteinase 11 \\
\hline H19520 & STMN2 & 4 & 5300 & Stathmin-like 2 \\
\hline T84395 & KLK6 & 3.5 & 2000 & Kallikrein 6 (neurosin, zyme) \\
\hline BC012885 & TEM7R & 3.2 & 2500 & Tumour endothelial marker 7-related precursor \\
\hline BC019385 & FABP5 & 3 & 9500 & Fatty acid binding protein 5 \\
\hline H81304 & ANXA9 & 3 & 1500 & Annexin A9 \\
\hline
\end{tabular}

Signal intensity is the average of the control (untreated) samples.

50 and $500 \mathrm{pg} / \mathrm{ml}$ is shown in Figs $1-3$. We quantified the expression of three genes: IL-8, CSF-2 and AKR1B1. The real-time analysis showed that IL-8 mRNA increased in all six samples treated with IL-1 $\beta$ relative to the corresponding control cells from the same patients (Fig. 1, mean change 31-fold, range 2 - to 100 -fold, $P<0.03$ ). Similarly, CSF2 mRNA increased in all six samples treated with IL-1 $\beta$ (Fig. 2 , mean change 21 -fold, range 1.8 - to 50 -fold, $P=0.03$ ). AKR1B1 mRNA increased in all six samples treated with IL-1 $\beta$ (Fig. 3, mean change 3.1-fold, range 1.2- to 5.9-fold, $P=0.03)$. The data are consistent with and validate those obtained through the microarray expression profiling analysis, although the levels of fold change are not the same as in the microarray analysis (see Tables). Note that the hybridisation signal for the AKR1B1 cDNA is higher than for IL-8 or CSF2 in both untreated cells and after IL-1 $\beta$



Figure 1 Real-time RT-PCR for IL-8 on HESCs treated with either 50 (samples $1-3$ ) or $500 \mathrm{pg} / \mathrm{ml}$ IL-1 $\beta$ (samples 4-6), compared with untreated control cells from the same patients. Data from six different paired (control and IL-1 $\beta$-treated) samples are shown separately. All values are normalised to ribosomal $18 \mathrm{~S}$. The results for each sample are shown relative to the level of IL-8 in a reference endometrial RNA sample, used to produce a standard curve for the assay. IL-1 $\beta$ treatment increased IL-8 mRNA expression by an average of 31-fold (range 2- to 100-fold, both doses considered together) and this increase was statistically significant $(P<0.03)$. treatment, but its increment is much less than IL-8 and CSF2 after IL-1 $\beta$ treatment.

\section{Discussion}

By using a cDNA microarray the changes in the transcriptome of HESCs in response to the cytokine IL-1 $\beta$ were determined. Twenty-nine genes which are differentially expressed were identified. These fall into several functional categories, reflecting the multiple overlapping actions of this pleiotropic cytokine. By far the largest group of upregulated genes were immune modulators and cytokines. Several genes in this group have previously been reported to be upregulated by IL-1 $\beta$, including IL-8, IL-6, CXCL1 (GRO $\alpha)$, CXCL2 (GRO $\beta)$, CCL2 (MCP-1),

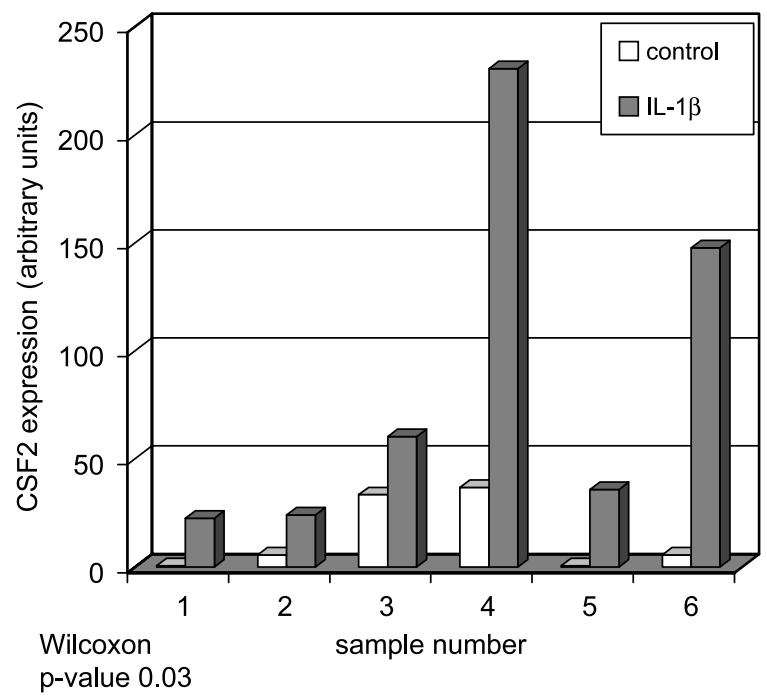

Figure 2 Real time RT-PCR for CSF2 on HESCs treated with either 50 (samples 1-3) or $500 \mathrm{pg} / \mathrm{ml} \mathrm{IL-1 \beta}$ (samples 4-6), compared with untreated control cells from the same patients. Data from six different paired samples are shown separately. All values are normalised to ribosomal 18S. The results for each sample are shown relative to the level of CSF2 in a reference endometrial RNA sample, used to produce a standard curve for the assay. IL-1 $\beta$ treatment increased CSF2 mRNA expression by an average of 2-fold (range 1.8- to 50-fold, both doses considered together) and this increase was statistically significant $(P=0.03)$. 


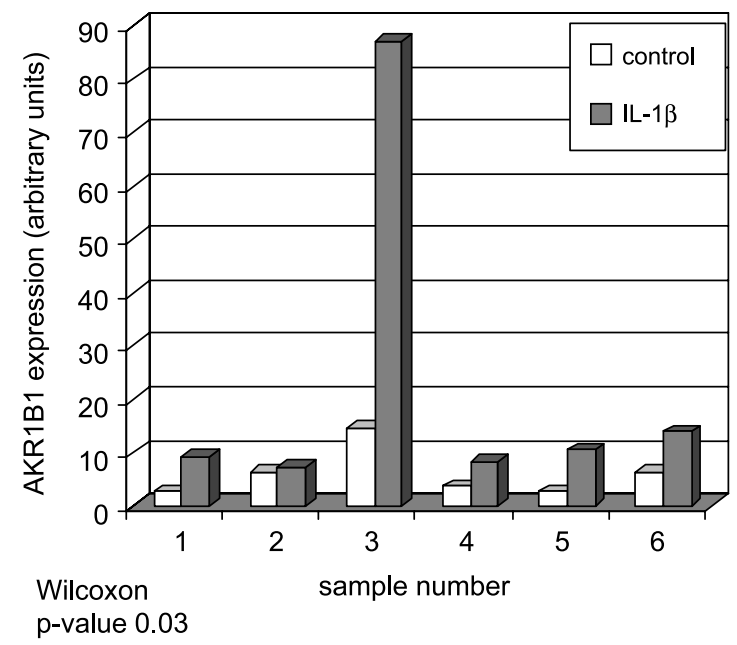

Figure 3 Real time RT-PCR for AKR1B1 on HESCs treated with either 50 (samples $1-3$ ) or $500 \mathrm{pg} / \mathrm{ml} \mathrm{IL-1 \beta}$ (samples 4-6), compared with untreated control cells from the same patient. Data from six different paired samples are shown separately. All values are normalised to ribosomal $18 \mathrm{~S}$. The results for each sample are shown relative to the level of AKR1B1 in a reference endometrial RNA sample, used to produce a standard curve for the assay. IL-1 $\beta$ treatment increased AKR1B1 mRNA expression by an average of 3.1-fold (range 1.2- to 5.9-fold, both doses considered together) and this increase was statistically significant $(P=0.03)$.

CSF2 and CSF3 (Arici et al. 1993, Chegini et al. 1999, Nasu et al. 2001), confirming that the arrays were performed correctly. In addition to chemokines and cytokines previously known to be upregulated by IL-1 $\beta$ in endometrium, several new immune regulators were up increased in HESCs, including CCL-7 (MCP-3), CCL13 (MCP-4), C3, CXCL5 (ENA-78), TNFAIP6 and IL-1 $\beta$ itself, indicating autocrine upregulation. There is a clear upregulation of both types of chemokines: the CC motif chemokines, which mainly attract and activate mononuclear cells, and the CXC motif chemokines, including IL-8 and CXCL1, which are responsible for recruitment and activation of human neutrophils. Just prior to the onset of menstruation there is a large influx of neutrophils into the endometrium, and it has been proposed that this may be due to IL-8 upregulation, since IL-8 strongly induces the attachment of neutrophils to endothelial cells (Schleimer \& Rutledge 1986, Milne et al. 1999). IL-8 expression is normally repressed in endometrium by the action of progesterone, and following progesterone withdrawal IL-8 is upregulated around blood vessels. Since we have shown, also with real-time RT-PCR, that IL-8 is strongly upregulated in stromal cells by the action of IL- $1 \beta$ in the absence of progesterone, the upregulation of IL-8 in endometrium prior to menstruation may be in part due to the action of IL-1 $\beta$ once progesterone levels begin to decline.

In addition to its actions in normal endometrium, it has been proposed that inflammatory cytokines such as IL-1 $\beta$ play an important role in the establishment and maintenance of ectopic endometriotic explants (Lebovic et al.
2001). Levels of IL-1 $\beta$ are elevated in the peritoneal fluid of women with endometriosis and IL-1 $\beta$ has been shown to upregulate cytokines and growth factors which may contribute to neovascularisation and monocyte chemotaxis in endometriotic explants. Indeed some of the factors which are upregulated by IL-1 $\beta$ such as IL- 8 have direct angiogenic effects on blood vessels (Lebovic et al. 2000). Monocytes within endometriotic explants also secrete other angiogenic growth factors, such as vascular endothelial growth factor, which may play a role in establishment of the disease (McLaren et al. 1996).

In the event of pregnancy, the process of decidualisation is accompanied by the invasion and differentiation of fetal trophoblast into the maternal decidua. Several of the cytokines and growth factors upregulated by IL-1 $\beta$ play an important role in this process. CSF2 is the major growth factor for granulocyte and macrophage proliferation, differentiation and survival, but it also stimulates proliferation of non-haemopoietic cell types (Rasko \& Gough 1994). Indeed, CSF2 is a growth factor for trophoblast and other placental cells (Giacomini et al. 1995), leading to improved placental functioning and fetal survival. IL-1 $\beta$ stimulates the trophoblast to release hCG through a mechanism involving IL-6 (Masuhiro et al. 1991). In pregnancy therefore, growth factors stimulated in HESCs by IL- $1 \beta$ may control trophoblast differentiation in the decidua. Indeed, IL-1 $\beta$ levels are reported to be decreased in endometrium of women with recurrent miscarriage, suggesting that a failure to activate the pathways downstream of IL-1 $\beta$ may contribute to pregnancy failure (von Wolff et al. 2000).

Both menstruation and decidualisation involve extensive remodelling of the extracellular matrix (ECM). The matrix metalloproteinase (MMP) gene family is involved in both physiological and pathological ECM remodelling such as occurs in embryonic development, tissue repair and tumour progression (Matrisian 1990). The expression of endometrial MMPs during the menstrual cycle is regulated by steroid hormones and various cytokines, including IL-1 $\beta$ and tumour necrosis factor- $\alpha$ (TNF- $\alpha$ ) (Salamonsen \& Wolley 1999). IL-1 $\alpha$ has previously been reported to upregulate MMPs $1,2,3,7$ and 9 , and IL-1 $\beta$ upregulates MMP3 via ERK and p38 MAP kinase phosphorylation (Osteen et al. 1997, Singer et al. 2002, Strakova et al. 2003). These effects are antagonised by progesterone, suggesting that ECM remodelling in nonpregnant endometrium is held in check until progesterone levels decline. The upregulation of MMP12 (metalloelastase) and of MMP1 (collagenase), and the downregulation of MMP11 (stromelysin-3) were found. This singular pattern of expression may suggest that IL-1 $\beta$ induces the degradation of collagen and elastin whereas the effects of stromelysin-3 (MMP11) are arrested. MMP11 has the capacity to degrade the fibronectin and laminin components of the ECM. Since decidualisation is accompanied by the increased deposition of laminin and fibronectin, this process may be assisted by reduced MMP11 activity. The proteins kallikrein 6 and annexin A9, 
which are able to degrade and aggregate ECM proteins, were also downregulated and the protease inhibitor plasminogen activator inhibitor type 2 (PAI2) was upregulated. PAI2 is thought to serve as a primary regulator of plasminogen activation in the extravascular compartment. As well as enabling tissue remodelling, many of these proteases can regulate the actions of cytokines and chemokines, by proteolytic cleavage of precursors, or by inactivation of the mature forms. The precise and unique pattern of proteases and their inhibitors, which is induced by IL-1 $\beta$, may serve both purposes.

An exciting feature of this study is the identification of several new genes representing novel functions not previously known to be regulated by IL-1 $\beta$ in endometrium. For example, AKR1B1 is an aldose reductase enzyme that is secreted into the extracellular space where it is has multiple functions: it can reduce benzaldehyde, glyceraldehyde, glucose and several other carbonyl-containing compounds. AKR1B1, with superoxide dismutase-2 and metallothioneins, may act to protect cells from unstable reactive radicals and heavy metals implicated in the pathology of a number of organs including endometrium (Kagi 1991, Ishikawa et al. 1993, Sies 1993). These toxic compounds and oxygen free radicals may be detrimental to the attachment, implantation and development of the embryo (Orsi \& Leese 2001) and AKR1B1 may play a role around the time of implantation to protect the embryo and to create a safe environment for reception of a fertilised ovum. Similarly at menstruation, these proteins may serve to mop up free radicals generated by highly activated leukocytes during tissue necrosis. The second aspect of this poorly understood enzyme is that AKR1B1 has been associated with prostaglandin (PG) $F$ synthase activity. The corresponding bovine enzyme, AKR1B5, can transform $\mathrm{PGH} 2$ into $\mathrm{PGF} 2 \alpha$ in reproductive tissue (Madore et al. 2003). This leads us to hypothesise that AKR1B1, together with cyclooxygenases 1 and 2, may be an important enzyme to synthesis PGs in human endometrium. Finally, AKR1B1 has recently been shown to be an obligatory mediator of TNF- $\alpha$ signalling, leading to an increase in the expression of adhesion molecules and increased binding of monocytes to the endothelium (Ramana et al. 2004). Thus AKR1B1 may be involved in mechanism by which IL-1 $\beta$ recruits monocytes to the endometrium.

Among the downregulated genes, STMN2 expression decreased at both doses of IL-1 $\beta$. This poorly defined peptide plays a 'functional' role in neuronal differentiation and in modulating membrane interaction with the cytoskeleton during neurite outgrowth in the adult brain. It also plays a 'development' role during embryonic and perinatal periods, by regulating cell proliferation, differentiation and maturation during tissue development (Koppel et al. 1990). In addition, we identified a 3 -fold decrease in transcripts encoding FABP5, which binds free fatty acids and regulates lipid metabolism and transport. The high expression of FABP5 in the endometrium in the absence of IL-1 $\beta$ suggests an important role for it in cholesterol transport in this tissue, perhaps for local steroid hormone biosynthesis or steroid hormone binding.

In conclusion, the data presented herein offer the opportunity to investigate the multiple roles of IL-1 $\beta$ in stromal cells of the endometrium. IL-1 $\beta$ is expressed in vivo at the decision point when endometrium may undergo menstruation or decidualisation and implantation. Many of the genes regulated by IL-1 $\beta$ in stromal cells could play a role in both these outcomes. The study identified new genes involved in functions previously known to be regulated by IL-1 $\beta$ in endometrium such as leukocyte recruitment and activation as well as matrix remodelling (MMPs). However, we also identified novel functions which appear to be regulated by IL-1 $\beta$ in endometrium, including several genes involved in detoxification/free radical protection, and fatty acid metabolism. The identification of genes regulated directly in the stroma by IL-1 $\beta$ in this study will permit investigation of how IL$1 \beta$ is involved in situations where menstruation or decidualisation and implantation are disturbed. For example in recurrent miscarriage, where IL-1 $\beta$ is reported to be decreased, we will seek to determine whether the downstream genes regulated by IL-1 $\beta$ are also altered. This will permit investigation of the role of IL-1 $\beta$ in very early events of pregnancy.

\section{Acknowledgements}

The authors would like to thank Cris Print, Amanda Evans and Peter Ellis for their helpful advice on array analysis. Microarrays were kindly provided by the BBSRC microarray group in the Department of Pathology, Cambridge (BBSRC grant no. 8/EGH16106). A M S was supported by the Meres Senior Research Studentship from St John's College Cambridge. The authors declare that there is no conflict of interest that would prejudice the impartiality of this scientific work.

\section{References}

Arici A, Head JR, MacDonald PC \& Casey ML 1993 Regulation of interleukin-8 gene expression in human endometrial cells in culture. Molecular and Cellular Endocrinology 94 195-204.

Barañao RI, Piazza A, Rumi L \& Polak de Fried E 1992 Predictive value of interleukin-1 in supernatants of human embryo culture. Fertility and Sterility $\mathbf{5 8}$ Suppl 3.

Bigonnesse F, Labelle Y \& Akoum A 2001 Triphasic expression of interleukin-1 receptor type I in human endometrium throughout the menstrual cycle of fertile women and women with unexplained infertility. Fertility and Sterility 75 79-87.

Boucher A, Kharfi A, Al-Akoum M, Bossu P \& Akoum A 2001 Cycledependent expression of interleukin-1 receptor type II in the human endometrium. Biology of Reproduction 65 890-898.

Chegini N, Tang XM \& Dou Q 1999 The expression, activity and regulation of granulocyte macrophage-colony stimulating factor in human endometrial epithelial and stromal cells. Molecular Human Reproduction 5 459-466.

De los Santos MJ, Mercader A, Frances A, Portoles E, Remohi J, Pellicer A \& Simon C 1996 Role of endometrial factors in regulating secretion of components of the immunoreactive human 
embryonic interleukin-1 system during embryonic development. Biology of Reproduction 54 563-574.

Dinarello CA 1996 Biologic basis for interleukin-1 in disease. Blood 87 2095-2147.

Evans AL, Sharkey AS, Saidi SA, Print CG, Catalano RD, Smith SK \& Charnock-Jones DS 2003 Generation and use of a tailored gene array to investigate vascular biology. Angiogenesis 6 93-104.

Frank GR, Brar AK, Jikihara H, Cedars MI \& Handwerger S 1995 Interleukin-1 beta and the endometrium: an inhibitor of stromal cell differentiation and possible autoregulator of decidualization in humans. Biology of Reproduction 52 184-191.

Giacomini G, Tabibzadeh SS, Satyaswaroop PG, Bonsi L, Vitale L, Bagnara GP, Strippoli P \& Jasonni VM 1995 Epithelial cells are the major source of biologically active granulocyte macrophage colony-stimulating factor in human endometrium. Human Reproduction $103259-3263$.

Ishikawa M, Nakata T, Yaginuma Y, Nishiwaki K, Goishi K \& Saitoh S 1993 Expression of superoxide dismutase (SOD) in adenomyosis. American Journal of Obstetrics and Gynecology 169 730-734.

Kagi JH 1991 Overview of metallothionein. Methods in Enzymology 205 613-626.

Kauma S, Matt D, Strom S, Eierman D \& Turner T 1990 Interleukin-1 beta, human leukocyte antigen HLA-DR alpha, and transforming growth factor-beta expression in endometrium, placenta, and placental membranes. American Journal of Obstetrics and Gynecology 163 1430-1437.

Koppel J, Boutterin MC, Doye V, Peyro-Saint-Paul H \& Sobel A 1990 Developmental tissue expression and phylogenetic conservation of stathmin, a phosphoprotein associated with cell regulations. Journal of Biological Chemistry 265 3703-3707.

Krussel JS, Bielfeld P, Polan ML \& Simon C 2003 Regulation of embryonic implantation. European Journal of Obstetrics, Gynecology, and Reproductive Biology 110 S2 -S9.

Lebovic DI, Bentzien F, Chao VA, Garrett EN, Meng YG \& Taylor RN 2000 Induction of an angiogenic phenotype in endometriotic stromal cell cultures by interleukin-1beta. Molecular Human Reproduction 6 269-275.

Lebovic DI, Mueller MD \& Taylor RN 2001 Immunobiology of endometriosis. Fertility and Sterility 75 1-10.

Lebovic DI, Baldocchi RA, Mueller MD \& Taylor RN 2002 Altered expression of a cell-cycle suppressor gene, Tob-1, in endometriotic cells by cDNA array analyses. Fertility and Sterility $\mathbf{7 8}$ 849-854.

Madore E, Harvey N, Parent J, Chapdelaine P, Arosh JA \& Fortier MA 2003 An aldose reductase with 20 alpha-hydroxysteroid dehydrogenase activity is most likely the enzyme responsible for the production of prostaglandin $\mathrm{f} 2$ alpha in the bovine endometrium. Journal of Biological Chemistry 278 11205-11212.

Masuhiro K, Matsuzaki N, Nishino E, Taniguchi T, Kameda T, Li Y, Saji F \& Tanizawa O 1991 Trophoblast-derived interleukin-1 (IL-1) stimulates the release of human chorionic gonadotropin by activating IL-6 and IL-6-receptor system in first trimester human trophoblasts. Journal of Clinical Endocrinology and Metabolism 72 594-601.

Matrisian LM 1990 Metalloproteinases and their inhibitors in matrix remodeling. Trends in Genetics 6 121-125.

McLaren J, Prentice A, Charnock-Jones DS, Millican SA, Muller KH, Sharkey AM \& Smith SK 1996 Vascular endothelial growth factor is produced by peritoneal fluid macrophages in endometriosis and is regulated by ovarian steroids. Journal of Clinical Investigation $\mathbf{9 8}$ $482-489$

Milne SA, Critchley HO, Drudy TA, Kelly RW \& Baird DT 1999 Perivascular interleukin-8 messenger ribonucleic acid expression in human endometrium varies across the menstrual cycle and in early pregnancy decidua. Journal of Clinical Endocrinology and Metabolism $842563-2567$.

Nasu K, Fujisawa K, Arima K, Kai K, Sugano T \& Miyakawa I 2001 Expression and regulation of growth-regulated oncogene alpha in human endometrial stromal cells. Molecular Human Reproduction $7741-746$
Noyes RW, Hertig AT \& Rock J 1975 Dating the endometrial biopsy. American Journal of Obstetrics and Gynecology 122 262-263.

Orsi NM \& Leese HJ 2001 Protection against reactive oxygen species during mouse preimplantation embryo development: role of EDTA, oxygen tension, catalase, superoxide dismutase and pyruvate. Molecular Reproduction and Development 59 44-53.

Osteen KG, Sierra-Rivera E, Keller NR \& Fox DB 1997 Interleukin-1 alpha opposes progesterone-mediated suppression of MMP-7. A possible role of this cytokine during human implantation. Annals of the New York Academy of Sciences 828 137-145.

Petalidis L, Bhattacharyya S, Morris GA, Collins VP, Freeman TC \& Lyons PA 2003 Global amplification of mRNA by template-switching PCR, linearity and application to microarray analysis. Nucleic Acids Research 31 e142.

Ramana KV, Bhatnagar A \& Srivastava SK 2004 Inhibition of aldose reductase attenuates TNF-alpha-induced expression of adhesion molecules in endothelial cells. FASEB Journal 18 1209-1218.

Rasko JEJ \& Gough NM 1994 Granulocyte macrophage-colony stimulating factor. In The Cytokine Handbook, 2, pp 342-369. Ed. A Thomson. New York: Academic Press.

Salamonsen LA \& Woolley DE 1999 Menstruation: induction by matrix metalloproteinases and inflammatory cells. Journal of Reproductive Immunology 44 1-27.

Schleimer RP \& Rutledge BK 1986 Cultured human vascular endothelial cells acquire adhesiveness for neutrophils after stimulation with interleukin 1, endotoxin, and tumor-promoting phorbol diesters. Journal of Immunology 136 649-654.

Sharkey A 1998 Cytokines and implantation. Reviews in Reprod 3 $52-61$.

Sheth KV, Roca GL, Al-Sedairy ST, Parhar RS, Hamilton CJCM \& Al-Abdul Jabbar F 1991 Prediction of successful embryo implantation by measuring interleukin-1- alpha and immunosuppressive factor(s) in preimplantation embryo culture fluid. Fertility and Sterility 55 952-957.

Sies H 1993 Strategies of antioxidant defense. European Journal of Biochemistry 215 213-219.

Simon C, Frances A, Piquette G, Hendrickson M, Milki A \& Polan ML 1994 Interleukin-1 system in the materno-trophoblast unit in human implantation: immunohistochemical evidence for autocrine/paracrine function. Journal of Clinical Endocrinology and Metabolism 78 847-854.

Simon C, Pellicer A \& Polan ML 1995 Interleukin-1 system crosstalk between embryo and endometrium in implantation. Human Reproduction 10 43-54.

Simon C, Gimeno MJ, Mercader A, O'Connor JE, Remohi J, Polan ML \& Pellicer A 1997 Embryonic regulation of integrins beta 3, alpha 4 , and alpha 1 in human endometrial epithelial cells in vitro. Journal of Clinical Endocrinology and Metabolism 82 2607-2616.

Singer CF, Kronsteiner N, Marton E, Walter I, Kubista M, Czerwenka K, Schreiber M, Tschugguel W, Wieser F \& Kubista E 2002 Interleukin-1 system and sex steroid receptor gene expression in human endometrial cancer. Gynecologic Oncology $\mathbf{8 5}$ 423-430.

Spandorfer SD, Neuer A, Liu HC, Bivis L, Clarke R, Veeck L, Witkin SS \& Rosenwaks Z 2000 Interleukin-1 levels in the supernatant of conditioned media of embryos grown in autologous endometrial coculture: correlation with outcome after in vitro fertilization. American Journal of Reproduction \& Immunology 43 6-11.

Strakova Z, Szmidt M, Srisuparp S \& Fazleabas AT 2003 Inhibition of matrix metalloproteinases prevents the synthesis of insulin-like growth factor binding protein-1 during decidualization in the baboon. Endocrinology 144 5339-5346.

Strakova Z, Mavrogianis P, Meng X, Hastings JM, Jackson KS, Cameo P, Brudney A, Knight O \& Fazleabas AT 2005 In vivo infusion of interleukin-1\{beta\} and chorionic gonadotropin induces endometrial changes that mimic early pregnancy events in the baboon. Endocrinology 146 4097-4104. 
Tabibzadeh S \& Sun XZ 1992 Cytokine expression in human endometrium throughout the menstrual cycle. Human Reproduction 7 $1214-1221$.

Tusher VG, Tibshirani R \& Chu G 2001 Significance analysis of microarrays applied to the ionizing radiation response. PNAS 98 $5116-5121$.

Viganò P, Somigliana F, Mangioni S, Vignali M, Vignali M \& Di Blasio AM 2002 Expression of interleukin-10 and its receptors is upregulated in early pregnant versus cycling human endometrium. Journal of Clinical Endocrinology and Metabolism 87 5730-5736. von Wolff M, Thaler CJ, Strowitzki T, Broome J, Stolz W \& Tabibzadeh S 2000 Regulated expression of cytokines in human endometrium throughout the menstrual cycle: dysregulation in habitual abortion. Molecular Human Reproduction 6 627-634.

Received 9 February 2005

First decision 3 March 2005

Revised manuscript received 2 August 2005

Accepted 16 August 2005 